\title{
PENGARUH STATUS SOSIAL EKONOMI ORANG TUA TERHADAP PRESTASI BELAJAR SISWA (Studi Kasus Siswa Kelas VIII SMP Negeri 1 Jember Tahun Ajaran 2016/2017)
}

\author{
Lilis Nur Chotimah ${ }^{1}$, Hety Mustika Ani ${ }^{1}$, Joko Widodo ${ }^{1}$ \\ ${ }^{1}$ Program Studi Pendidikan Ekonomi, Fakultas Keguruan dan Ilmu Pendidikan, Universitas Jember
}

\begin{abstract}
This study was conducted to determine the significant the of economic social status of parents to student achievement (Case Study on The VIII / Eight Grade Students of SMP 1 Jember in 2016/2017 Academic Years). The method to determine the location of the research using purposive area that is at SMP 1 Jember. Determination the number of respondents in this study using simple random sampling method is 81 respondents. Methods of collection data used consisted of methods: questionnaires, interviews, observations, and documentation. Analysis of the data used is descriptive analysis and inferential analysis/statistics by using simple regression line analysis, analysis variance of the regression line, the F test, the effectiveness of the regression line, and Standard Error of Estimate. The results showed that there was a significant effect of variables economic social status of parents to student achievement (Case Study on The VIII / Eight Grade Students of SMP 1 Jember In 2016/2017 Academic Years), which can be seen from the magnitude of $F=$ $268,491>$ Ftable $3,112=$ with a significance level of $F=0,000<0,05$. The amount of the percentage of economic social status of parents to student achievement by $77.3 \%$, while the remaining $22.7 \%$ influenced by other variables not examined in this study, such an interest, ingenuity, talent, intelligence, and others.
\end{abstract}

Keywords: Economic social status of parents and student achievement

\section{PENDAHULUAN}

Pendidikan merupakan salah satu kebutuhan hidup yang prosesnya berlangsung seumur hidup dan dalam pelaksanaannya dapat terwujud melalui tiga jalur yaitu pendidikan informal, pendidikan nonformal, dan pendidikan formal. Pendidikan informal adalah pendidikan yang terjadi di dalam kehidupan keluarga dimana orang tua sangat berperan dalam pembentukan watak, kepribadian serta perkembangan emosional anak. Pendidikan non formal adalah pendidikan yang terjadi di masyarakat dan pendidikan formal adalah pendidikan yang diselenggarakan di sekolah melalui kegiatan belajar mengajar secara berjenjang dan berkesinambungan. Sekolah memberikan kesempatan kepada setiap anak untuk mengembangkan kemampuan-kemampuan dirinya, yang masih bersifat potensial sehingga bermanfaat untuk kepentingan hidupnya sebagai individu maupun sebagai warga negara. Oleh karena itu pendidikan menjadi tanggung jawab bersama antara keluarga, masyarakat, dan pemerintah.

Pendidikan melibatkan keluarga, masyarakat, pemerintah. Ketiga hal tersebut saling berkaitan satu sama lain. Dalam pelaksanaan pendidikan di sekolah terdapat proses belajar mengajar yang akan menghasilkan perubahan dalam individu dan kecakapan pada diri individu. Perubahan-perubahan itu berwujud pengetahuan atau pengalaman baru yang diperoleh individu dari usaha dalam belajar.

Status sosial ekonomi seseorang tentu mempunyai peranan terhadap perkembangan anak-anaknya. Keluarga yang mempunyai status sosial ekonomi yang baik, tentu akan memberi perhatian yang baik pula pada pemenuhan kebutuhan sehari-hari dan akan memikirkan masa depan anak-anaknya. Menurut Sugihartono, dkk (2015:3) menyatakan status sosial ekonomi orang tua, meliputi tingkat pendidikan orang tua, pekerjaan orang tua, penghasilan orang tua. 
Keluarga yang memiliki status sosial ekonomi kurang mampu, akan cenderung untuk memikirkan bagaimana pemenuhan kebutuhan pokok, sehingga perhatian untuk meningkatkan pendidikan anak juga kurang.

Kondisi status sosial ekonomi orang tua merupakan salah satu faktor eksternal yang mempengaruhi belajar. Cara orang tua mendidik anaknya besar pengaruhnya terhadap prestasi belajar anak. Hal ini dipertegas oleh Sutjipto Wirowidjojo (dalam Slameto, 2015:61) dengan pernyataannya yang menyatakan bahwa: Keluarga adalah lembaga pendidikan yang pertama dan utama. Keluarga yang sehat besar artinya untuk pendidikan dalam ukuran kecil, tetapi bersifat menentukan untuk pendidikan dalam ukuran besar yaitu pendidikan bangsa, negara, dan dunia Melihat pernyataan di atas, dapatlah dipahami betapa pentingnya peranan keluarga di dalam pendidikan anaknya. Cara orang tua mendidik anak-anaknya akan berpengaruh terhadap belajarnya.

Peranan ekonomi orang tua secara umum dapat dikatakan mempunyai pengaruh yang positif terhadap peningkatan prestasi belajar siswa. Hal ini disebabkan proses belajar mengajar siswa membutuhkan alat-alat atau seperangkat pengajaran atau pembelajaran, dimana alat ini untuk memudahkan siswa dalam mendapatkan informasi, pengelolaan bahan pelajaran yang diperoleh dari sekolah. Hal ini didukung oleh pendapat Gerungan (2004:196) menyatakan bahwa keadaan sosio-ekonomi keluarga tentulah berpengaruh terhadap perkembangan anakanak, apabila kita perhatikan bahwa dengan adanya perekonomian yang cukup, lingkungan material yang dihadapi anak dalam keluarga itu lebih luas, ia mendapat kesempatan yang lebih luas untuk mengembangkan bermacam-macam kecakapan yang tidak dapat ia kembangkan apabila tidak ada prasarananya. Hal ini didukung oleh pendapat Djaali (2014:9) menyatakan bahwa pendidikan orang tua, status ekonomi, rumah kediaman, persentase hubungan orang tua, perkataan, dan bimbingan orang tua mempengaruhi pencapaian prestasi belajar anak.

Keadaan ekonomi orang tua siswa turut mendukung siswa dalam pengadaan sarana dan prasarana belajar, yang akan memudahkan dan membantu pihak sekolah untuk peningkatan proses belajar mengajar di sekolah. Pembelajaran membutuhkan biaya yang tidak sedikit. Alatalat belajar mengajar yang dimaksud buku-buku pelajaran, pensil, penggaris, buku-buku lembar kerja soal ( LKS ), laptop, penghapus, dan lain-lain.

Pendidikan yang baik dapat dinikmati oleh anak apabila orang tua peduli pada masa depan anaknya. Menurut Slameto (2015:61) menyatakan bahwa orang tua yang kurang atau tidak memperhatikan pendidikan anaknya, misalnya mereka acuh tak acuh terhadap belajar anaknya, tidak memperhatikan sama sekali akan kepentingan-kepentingan dan kebutuhankebutuhan anaknya dalam belajar, tidak mengatur waktu belajarnya, tidak menyediakan atau melengkapi alat belajarnya, tidak memperhatikan apakah anak belajar atau tidak, tidak mau tahu bagaimanakah kemajuan belajar anaknya, kesulitan-kesulitan yang dialami dalam belajar dan lain-lain, dapat menyebabkan anak tidak atau kurang berhasil dalam belajarnya. Mungkin anak sendiri sebetulnya pandai, tetapi karena cara belajarnya tidak teratur, akhirnya kesukarankesukaran menumpuk sehingga mengalami ketinggalan dalam belajarnya dan akhirnya anak malas belajar. Hasil yang didapatkan, nilai atau hasil belajarnya tidak memuaskan bahkan mungkin gagal dalam studinya. Hal ini dapat terjadi pada anak dari keluarga yang kedua orang tuanya terlalu sibuk mengurusi pekerjaan mereka. 
Keragaman kondisi sosial ekonomi orang tua siswa kelas VIII di SMP Negeri 1 Jember sangat bermacam-macam. Ada yang sangat baik perhatiannya karena orang tua itu sudah menyadari arti penting pendidikan untuk masa depan anaknya dan ada juga yang sangat acuh terhadap anaknya. Pada dasarnya orang tua tidak mencari nafkah saja tetapi juga memberikan perhatian khusus pada perkembangan anaknya.

Berdasarkan observasi di SMP 1 Jember merupakan sekolah menengah pertama dengan kondisi status sosial ekonomi orang tua yang beragam. Latar belakang ekonomi orang tua tersebut berpengaruh pada kemampuan untuk membiayai pendidikan anak-anaknya dan melengkapi kebutuhan belajarnya. Sehingga keadaan tersebut dapat dikatakan sebagai salah satu faktor pengaruh status sosial ekonomi terhadap prestasi belajar.

\section{METODE PENELITIAN}

Penelitian ini merupakan penelitian deskriptif kuantitatif, yaitu untuk mengetahui pengaruh status sosial ekonomi orang tua terhadap prestasi belajar siswa (studi kasus siswa kelas VIII SMP Negeri 1 Jember tahun ajaran 2016/2017). Metode penentuan lokasi penelitian menggunakan metode purposive area yaitu di SMP Negeri 1 Jember. Penentuan jumlah responden dalam penelitian ini menggunakan metode simple random sampling yaitu sebanyak 81 responden. Metode pengumpulan data yang digunakan terdiri dari metode: angket, wawancara, observasi, dan dokumentasi. Uji instrumen data dalam penelitian ini menggunakan uji validitas dan uji reliabilitas. Teknik pengolahan data dalam penelitian ini menggunakan editing, skoring, dan tabulasi. Analisis data yang digunakan adalah analisis deskriptif dan analisis inferensial/statistik yaitu dengan menggunakan analisis garis analisis regresi sederhana dengan rumus sebagai berikut:

$$
\hat{\mathrm{Y}}=\mathrm{a}+\mathrm{bX}+e i
$$

Untuk analisis varian garis regresi yaitu untuk mengetahui kuat tidaknya atau tingkat keeratan variabel status sosial ekonomi orang tua terhadap prestasi belajar siswa (studi kasus siswa kelas VIII SMP Negeri 1 Jember tahun ajaran 2016/2017) yaitu dengan rumus sebagai berikut:

$$
\mathrm{Ry}=\sqrt{\frac{a \sum X Y}{\sum Y^{2}}}
$$

Sedangkan uji $\mathrm{F}$ yaitu untuk mengetahui pengaruh yang signifikan variabel status sosial ekonomi orang tua terhadap prestasi belajar siswa (studi kasus siswa kelas VIII SMP Negeri 1 Jember tahun ajaran 2016/2017). dengan rumus sebagai berikut:

$$
\mathrm{F}_{\text {reg }}=\frac{R_{y}^{2}(1)(N-m-1)}{m\left(1-R_{Y}^{2}(1)\right)}
$$

Selanjutnya, untuk uji efektivitas garis regresi yaitu untuk mengetahui berapa besar (\%) pengaruh variabel status sosial ekonomi orang tua terhadap prestasi belajar siswa (studi kasus siswa kelas VIII SMP Negeri 1 Jember tahun ajaran 2016/2017). 


\section{HASIL DAN PEMBAHASAN \\ Hasil Penelitian}

Berdasarkan hasil analisis garis regresi sederhana diperoleh $\mathrm{R}_{\text {square }}$ sebesar 0,773. Koefisien determinasi $\mathrm{R}_{\text {square }}$ dalam penelitian ini digunakan untuk mengukur besarnya pengaruh variabel bebas (X) dan variabel terikat (Y). Jenis analisis ini digunakan untuk mengetahui pengaruh yang signifikan dari variabel bebas yaitu variabel status sosial ekonomi orang tua terhadap prestasi belajar siswa (studi kasus siswa kelas VIII SMP Negeri 1 Jember tahun ajaran 2016/2017). Berdasarkan analisis data yang dilakukan diperoleh hasil dalam tabel berikut ini:

Tabel Ringkasan Uji F, Multiple R, dan R Square

\begin{tabular}{ccccccc}
\hline Variabel & F Hitung & F Tabel & Sig. F & $a$ & R & $\mathrm{R}_{\text {Square }}$ \\
\hline X terhadap Y & 268,491 & 3,112 & 0,000 & 0,05 & $0,879^{\mathrm{a}}$ & 0,773 \\
\hline \multicolumn{7}{c}{ Sumber: }
\end{tabular}

Tabel di atas menunjukkan bahwa $\mathrm{F}_{\text {hitung }}=268,491>\mathrm{F}_{\text {tabel }}=3,112$ dengan tingkat signifikansi $\mathrm{F}=0,000<a=0,05$. Hal ini menunjukkan bahwa variabel status sosial ekonomi orang tua mempunyai pengaruh yang signifikan terhadap prestasi belajar siswa (studi kasus siswa kelas VIII SMP Negeri 1 Jember tahun ajaran 2016/2017). Untuk koefisien determinasi $\mathrm{R}_{\text {Square }}$ sebesar 0,773 , yang dengan proporsi sumbangan variabel X terhadap Y sebesar 77,3\%. sedangkan sisanya yaitu $23,7 \%$ dipengaruhi variabel bebas lainnya yang tidak diteliti dalam penelitian ini seperti minat, kecerdasan, bakat, inteligensi dan lain-lain (Hakim (2001:94)). Hubungan antara status sosial ekonomi orang tua memiliki pengaruh yang signifikan terhadap prestasi belajar siswa (studi kasus siswa kelas VIII SMP Negeri 1 Jember tahun ajaran 2016/2017). dapat diketahui dari multiple R sebesar 0,879 dengan kategori hubungan yang sangat kuat.

\section{Pembahasan}

Berdasarkan hasil penelitian yang telah dilakukan, dapat diketahui bahwa ada pengaruh status sosial ekonomi orang tua terhadap prestasi belajar siswa secara signifikan. $\mathrm{NilaiF}_{\text {hit }}=$ $268,491>\mathrm{F}_{t} \quad=3.112$ dengan tingkat signifikansi $\mathrm{F}=0,000<\mathrm{a}=0,05$. Hal ini menunjukkan bahwa variabel status sosial ekonomi orang tua memiliki pengaruh yang signifikan terhadap prestasi belajar siswa kelas VIII SMP Negeri 1 Jember Kabupaten Jember tahun ajaran 2016/2017. Analisis varian garis regresi nilai koefisien korelasi sebesar bahwa nilai koefisien korelasi sebesar 0,897 berarti bahwa status sosial ekonomi orang tua (X) memiliki hubungan yang nyata/signifikan dengan prestasi belajar siswa kelas VIII SMP Negeri 1 Jember Kabupaten Jember tahun ajaran 2016/2017 (Y). Tingkat hubungan tersebut dapat dikategorikan sebagai hubungan yang sangat kuat. Analisis efektifitas garis regresi sebesar 77,3 yang termasuk kategori tinggi. Hal ini dikarenakan dengan adanya status sosial ekonomi orang tua tersebut (meliputi: pekerjaan, pendidikan, pendapatan) dapat mempengaruhi prestasi belajar siswa kelas VIII SMP Negeri 1 Jember Kabupaten Jember tahun ajaran 2016/2017.

Pekerjaan orang tua siswa di SMP Negeri 1 Jember kebanyakan adalah sebagai pedagang/wiraswasta dengan pendidikan yang rendah dan pendapatan yang hanya cukup untuk memenuhi kebutuhan sehari-hari. Adapun orang tua siswa yang bekerja sebagai PNS hanya 
beberapa orang saja. Menurut Slameto (2015:60), menyatakan siswa yang belajar akan menerima pengaruh dari keluarga berupa: cara orang tua mendidik, relasi antara anggota keluarga, suasana rumah tangga, dan keadaan ekonomi keluarga. Meskipun pendapatan yang diperoleh orang tua siswa hanya cukup untuk memenuhi kebutuhan hidup sehari-hari dan pendidikan orang tua siswa juga rendah, tetapi kesadaran orang tua siswa untuk memenuhi fasilitas belajar anaknya sudah cukup baik. Terbukti bahwa siswa sudah mempunyai meja dan kursi, meskipun hanya sekedar meja dan kursi belajar biasa. Siswa juga mempunyai buku panduan meskipun hanya buku LKS (Lembar Kerja Siswa).

Keluarga merupakan kelompok sosial, yang didalamnya akan terjadi tidakan sosial. Kehidupan sosial ekonomi keluarga yang layak akan tercipta suasana yang baik, nyaman, aman dan damai dan boleh dikatakan makmur, dimungkinan akan membawa dampak dalam proses belajar bagi anak-anak dalam satu keluarga berjalan baik. Status sosial ekonomi, keterlibatan orang tua adalah faktor yang sangat penting dalam prestasi siswa. Dengan perbedaan status sosial ekonomi yang berbeda dapat berpengaruh pada prestasi belajar siswa di sekolah.

Orang tua siswa juga mengijinkan anaknya mengikuti les untuk mata pelajaran tertentu. Biaya untuk mengikuti les juga tidak mahal karena membayarnya setiap kali pertemuan saja dan dalam 1 minggu hanya $2 x$ pertemuan. Jadi orang tua siswa tidak keberatan dalam membayarnya. Hal ini menandakan bahwa kesadaran orang tua terhadap pendidikan anaknya sudah tinggi. Ada juga orang tua siswa yang hanya bisa membelikan buku saja untuk anaknya, tetapi hal ini tidak membuat siswa malas dalam belajar karena siswa bisa meminjam buku di perpustakaan sekolah ataupun meminjam kepada teman yang mempunyai buku panduan. Siswa yang hanya mempunyai fasilitas belajar seadanya hanya mampu memanfaatkann fasilitas yang tersedia sebaik mungkin.

Pada dasarnya status sosial ekonomi orang tua merupakan salah satu faktor yang dapat mempengaruhi prestasi belajar siswa. Status sosial ekonomi tersebut adalah tingkat pekerjaan, tingkat pendidikan dan jumlah pendapatan yang diterima oleh orang tua setiap bulannya, oleh peneliti ketiga aspek tersebut dijadikan sebagai indikator dalam penelitian. Apabila status sosial ekonomi orang tua siswa baik maka kesempatan siswa untuk memperoleh fasilitas belajar di rumah yang lengkap semakin besar. Berbeda dengan status sosial ekonomi orang tua siswa yang kurang baik, kebanyakan siswa yang status sosial ekonomi nya kurang baik fasilitas belajarnya di rumah kurang lengkap. Kesimpulannya adalah bahwa semakin tinggi status sosial ekonomi orang tua maka fasilitas belajar anak di rumah akan semakin terpenuhi, dan siswa akan lebih terdorong dalam proses belajarnya, sehingga prestasi belajar siswa akan lebih meningkat.

Tingkat prestasi yang dimiliki oleh siswa dipengaruhi oleh beberapa faktor, salah satunya adalah status sosial ekonomi orang tua. Menurut Slameto (2015:63), menjelaskan bahwa keadaan ekonomi keluarga erat hubungannya dengan keberhasilan prestasi belajar anak. Kebutuhan-kebutuhan anak yang harus terpenuhi dalam proses belajar adalah makanan, pakaian, kesehatan, dan fasilitas belajar seperti ruang belajar, meja, kursi, penerangan, bukubuku. Fasilitas belajar ini hanya dapat terpenuhi jika orang tuanya mempunyai cukup uang.

Hipotesis penelitian yang menyatakan diduga ada pengaruh yang signifikan status sosial ekonomi orang tua terhadap prestasi belajar siswa kelas VIII SMP Negeri 1 Jember Kabupaten Jember tahun ajaran 2016/2017 dengan demikian tujuan dari penelitian ini, yaitu untuk mengetahui ada tidaknya pengaruh yang signifikan status sosial ekonomi dan orang tua 
terhadap prestasi belajar siswa SMP Negeri 1 Jember Kabupaten Jember tahun ajaran 2016/2017 dapat terpenuhi. Melalui hasil penelitian ini diketahui bahwa latar status sosial ekonomi orang tua dapat memberikan kontribusi yang positif terhadap prestasi belajar siswa, mengingat bahwa kedua variabel tersebut sama-sama mempunyai pengaruh terhadap prestasi belajar siswa terutama variabel status sosial ekonomi.

\section{KESIMPULAN DAN SARAN}

\section{Kesimpulan}

Berdasarkan hasil penelitian data dan pembahasan yang telah dilakukan bahwa status sosial ekonomi orang tua berpengaruh terhadap prestasi belajar. Besarnya pengaruh status sosial ekonomi orang tua terhadap prestasi belajar siswa kelas VIII SMP Negeri 1 Jember Kabupaten Jember Tahun Ajaran 2016/2017 yaitu sebesar 77,3\%. Jadi status sosial ekonomi orang tua mempunyai pengaruh yang signifikan terhadap prestasi belajar siswa kelas VIII SMP Negeri 1 Jember Kabupaten Jember Tahun Ajaran 2016/2017.

\section{Saran}

Saran yang dapat peneliti berikan yaitu bahwa keadaan status sosial ekonomi orang tua sangatlah penting, karena dengan keadaan status ekonomi orang tua yang baik maka akan dapat memenuhi fasilitas belajar anak, sehingga anak dapat belajar lebih maksimal sehingga prestasi belajar anak lebih meningkat. Fasilitas dari orang tua juga mendukung kelancaran dan kenyamanan proses belajar di rumah sehingga dapat mendukung pencapaian prestasi belajar siswa.

1. Bagi sekolah diharapkan adanya jalinan komunikasi dan kerjasama dengan orang tua dalam mendidik anak. Adanya kerjasama tersebut, dua belah pihak akan mendapatkan informasi yang penting tentang masalah dan kesulitan yang dialami anak sehingga memudahkan baik orang tua atau guru dalam penyelesaiannya.

2. Bagi siswa, hendaknya dapat memanfaatkan fasilitas dari orang tua dengan baik.

3. Bagi peneliti selanjutnya, diharapkan dapat mengembangkan penelitian sejenis dengan memasukkan variabel-variabel lain yang belum diteliti dalam penelitian ini.

\section{DAFTAR BACAAN}

Djaali.2004. Psikologi Pendidikan. Jakarta. PT Bumi Aksara

Gerungan.2004. Psikologi Sosial. Bandung. PT Refika Aditama

Hakim, T.2001. Belajar Secara Efektif. Yogyakarta: Fakultas Psikologi UGM

Slameto. 2015. Belajar dan Faktor-Faktor yang Mempengaruhinya. Jakarta : Rineka Cipta

Sugiyono, 2008. Statistika Untuk Penelitian, Jakarta : Alfabeta

Sugihartono, dkk. 2015. Psikologi Pendidikan. Yogyakarta: UNY Press 